\title{
O aprendizado de um ofício ou um caminho pelos livros didáticos: entrevista com Carlos Ogawa
}

Entrevista por Letícia Oliver Fernandes, Matheus de Paula Silva e Pedro José de Carvalho Neto

Transcrição por Letícia Oliver Fernandes, Marina de Almeida Spinola, Matheus de Paula Silva e Pedro José de Carvalho Neto

Revisão por Beatriz Gasques Favilla, Gabriel Yukio Shinoda Oliveira, Gabriele Maria Oliveira, Pedro José de Carvalho Neto e Yan Fernando Ferreira Catuaba

DOI: 10.11606/issn.2318-8855.v9i2p38-72 


\section{entrevista|}

Carlos Ogawa

Tendo sido umas das primeiras entrevistas realizadas para esse dossiê, chegamos para conversar com Carlos Ogawa munidos de todas as perguntas do mundo e sem saber o que esperar. Carlos, com toda a sua cordialidade e disposição, nos envolveu durante duas horas em uma entrevista que, por nós, poderia ter durado cinco. Ali, ainda em 2019, não tínhamos clareza do que queríamos para esse dossiê, mas, com certeza, essa conversa foi definidora para os rumos que tomamos.

Carlos nos conta, com clareza e riqueza de detalhes, sua trajetória na graduação e mestrado em História pela USP, mas, também, seu caminho como editor de livros didáticos em diferentes lugares - um mundo gigante e cheio de possibilidades para os historiadores. Do dia-a-dia de seu trabalho às suas opiniões sobre os diálogos entre a academia e a educação básica, Carlos encarou todas as nossas dúvidas de frente. Para os interessados em editoração, apresentamos nas próximas páginas, permeados pelo olhar de Carlos, um pequeno manual de como fazer - e de como não fazer - a produção de um livro didático.

Boa leitura a todas e a todos!

Revista Epígrafe: Carlos, a gente queria começar falando um pouco sobre o seu percurso antes de entrar no mercado editorial. Por que você escolheu fazer História? O que te levou a esse caminho?

Carlos Ogawa: Ah, bom... Não vou dizer que eu sempre gostei de História, mas eu sempre gostei muito de literatura, eu sabia que seria algo relacionado. Poderia ter sido Filosofia, Letras... Tanto que depois, no mestrado, eu fui trabalhar com retórica. Aqui na USP [Universidade de São Paulo], eu fui fazer matéria em tudo que é lugar: na Letras, na Filosofia, no MAE [Museu de Arqueologia e Etnologia]... Lembro que na época da inscrição para o vestibular, peguei o manual da FUVEST [Fundação 


\section{entrevista}

O aprendizado de um ofício ou um caminho pelos livros didáticos Universitária para o Vestibular] e não sabia muito bem o que uma pessoa de Letras fazia, o que uma pessoa de [Ciências] Sociais fazia. A Geografia era evidente, e eu não gostava, não tinha afinidade na escola. E... daí, foi, bom, História. E foi maravilhoso. O primeiro semestre foi muito difícil, porque era toda uma mudança, vindo de escola pública. E, depois, quando eu fui fazer matérias em outros departamentos, vi que eu teria sido igualmente feliz em qualquer uma delas. Menos Geografia [risos]. Brincadeira, hoje gosto de trabalhar com Geografia.

Na escola em que estudei, [Escola Estadual] Brasílio Machado, não tive História por mais de um ano - no segundo ano e na metade do terceiro. No primeiro ano, eu gostava muito da professora, mas não era algo determinante. Acho que foram mais experiências prévias, de leitura. Meu pai trabalhou em editora, então sempre teve muitos livros em casa. Eu gostava muito da enciclopédia lá de casa - sou da época da enciclopédia [risos]. Ali na década de 1980 e na década de 1990, eu gostava muito de ler e tal. E eu não optei por Filosofia porque na época, década de 1990, Filosofia não era obrigatória, existia eventualmente em algumas escolas, em uma ou outra escola pública. Eu realmente não sabia o que um filósofo fazia para sobreviver. Eu fui pragmático nessa escolha porque vim de escola pública, então eu tinha... Não sei se medo, mas não me sentia à vontade para escolher um curso sem saber como eu iria sobreviver logo em seguida. Era a época do [governo do] Fernando Henrique [Cardoso], de desemprego alto. Não sei dizer se era tão ruim quanto hoje, mas era bem ruim também.

Revista Epígrafe: Hoje a gente está mais acostumado a ver gente de escola pública na universidade. Quando você entrou aqui... Você entrou em aqui em 2001, não é? Isso significou alguma coisa para você na época, ou não? 


\section{entrevista|}

Carlos Ogawa

Carlos Ogawa: Eu não sei porque eu não tenho os dados. Existia um ambiente muito elitizado. Muitos dos meus vieram da escola pública, então tinha gente do Itaim Paulista, gente de Itaquera... Eu sou da Cidade Ademar, que fica ali perto da divisa de São Paulo com Diadema, então sempre tinha gente próxima, sabe? O pessoal do ABC. Claro, tinha o filho do professor, tinha, sei lá, a galera que entrava falando francês, imagino que ainda tenha, mas também tinha o cara que trabalhava no McDonald's. Foi uma experiência muito variada e para mim isso foi bem bacana, porque era um ambiente mais democrático, não tão segregado. Então você tinha gente rica mesmo e também tinha o truta lá, que terminava a aula e demorava mais de duas horas para chegar em casa.... Gente que conseguia vaga no CRUSP [Conjunto Residencial da Universidade de São Paulo] porque morava longe da universidade.

Revista Epígrafe: Nesse período da graduação, nesse início, como foi sua experiência? Você teve interesse pela área acadêmica? Foi uma coisa que te pegou logo no início?

Carlos Ogawa: Era uma relação muito adulta. Os professores diziam: “A bibliografia é essa"; “A avaliação é tal dia"; “Esse é o programa do curso"; “Então leiam esse texto para semana que vem"; "Vocês podem achar na biblioteca ou na xerox"; e era isso. Eu vim de uma experiência escolar, era uma escola que dava até certa liberdade, mas não tanta... Então, esse meu primeiro contato foi de muito encanto pela autonomia que eu tive para fazer as disciplinas, e depois no segundo semestre eu pirei, eu fui fazer Latim [risos], eu abria o Júpiter... Era um fichário ainda [risos] grande ali [na Seção de Alunos], eu ficava: "Nossa que legal tem curso disso". Os meus amigos que vieram da periferia piraram também. Teve um que foi fazer cultura armênia [risos].

Revista Epígrafe: E teve algum professor que te marcou? 


\section{entrevista}

O aprendizado de um ofício ou um caminho pelos livros didáticos

Carlos Ogawa: O Ulpiano [Toledo Bezerra de Meneses], os seminários dele. Eu ainda gosto muito dele. Agora ele deve estar bem velhinho, com seus 80 e tantos anos. Foi um professor que vinha para gente e dizia: “Vamos ler mesmo o documento, vamos ter uma relação íntima com a leitura". A proposta dele não era pegar um texto curto e malhar o texto, mas fazer hipóteses de leitura. É claro que depois a gente via que essa não era toda a prática do historiador, todas etapas de pesquisa, ainda assim era um método de estudo muito importante. Eu gostava muito dos cursos dele, os seminários - ele dava raríssimas aulas expositivas.

Eu tive experiências completamente diferentes com vários professores, que também foram importantes. Com a Marlene [Suano], no curso de Arqueologia; ela fez a sala catalogar toda a produção de mestrado e doutorado do MAE, de 1994 até 2005 - foi quando eu fiz o curso dela, estava bem no finalzinho da graduação. E no final, com a ajuda dela, pegamos essa bibliografia e tabulamos. Na aula final, ela avaliou o trabalho feito: "A produção do MAE é essa, tantos porcento de bibliografia atualizada", sabe? Isso foi uma experiência bem marcante. Foi o oposto do Ulpiano, é engraçado. Do micro para o macro, de você realmente sistematizar o conhecimento e explorar de outra forma.

Revista Epígrafe: Você entrou num curso que você não sabia muito bem como era. Aí, com o que você foi vendo nos primeiros semestres ou mesmo até o final, te agradou?

Carlos Ogawa: Agradou, sim. Hoje as informações circulam, hoje tem internet. Minha adolescência se passou num mundo onde as informações não circulavam, então eu realmente entrei aqui [na USP] sem saber o que era o curso, sem ter depoimentos de pessoas que estudaram, sem ter programa do curso disponível, porque eles ficavam 


\section{entrevista}

Carlos Ogawa

só aqui, pregados [no final do corredor]. O aluno só descobria qual era a ementa do curso no começo do semestre. Antes de entrar aqui, esperava um curso de História como o da escola, um sumário de livro didático, capítulo um, capítulo dois... Os cursos eram totalmente diferentes, eles tinham pré-requisitos, mas não eram obrigatórios, a grade era bem livre. Não sei como é hoje. Eles tentaram implantar um semestre ideal, mas ninguém respeitava [risos]. Eu fui fazer teoria no segundo ano e aí eu fiquei com o curso atrasado. Fui fazer as matérias de Brasil no terceiro e quarto ano, porque eu estava vendo que eu não ia me formar [risos]. Teve um ano que eu peguei aula de manhã, de tarde e de noite para cumprir crédito, porque nos anos anteriores eu estava lá, fazendo Grego, fazendo Latim...

Revista Epígrafe: Você fez o mestrado sobre Carlo Ginzburg, sobre retórica especificamente. Como foi essa sua chegada no mestrado? Você fez logo em seguida, você terminou em 2006 e, em 2007, você já emendou um mestrado. Como foi essa passagem?

Carlos Ogawa: Assim... Começou com o encontro com os textos do Francisco [Murari Pires], não sei se vocês lembram dele, acho que ele se aposentou já faz algum tempo, - Francisco Murari era professor de História Antiga aqui. Ele é uma pessoa maravilhosa! É engraçado que os textos dele são tão densos, tão densos, que realmente é um negócio meio difícil de ler, você tem que ficar lendo, relendo, lendo, relendo. E ele lia a produção mais recente em sala, isso gerava alguma incompreensão dos alunos, pois esperava-se que um historiador de Antiga desse uma história tradicional de História Antiga. “Então, vamos lá, gente, Gregos, período arcaico, clássico, helenístico...". E não era esse o espírito do Departamento [de História da USP] na época, pelo menos não era comum que os professores 


\section{entrevista}

O aprendizado de um ofício ou um caminho pelos livros didáticos trouxessem... Alguns professores davam cursos voltados para bibliografia, eu lembro que o Modesto [Florenzano] dava esses cursos bem panorâmicos e que também eram ótimos. Mas o Francisco trazia textos dele mesmo, que ele estava fazendo ali, temas sobre os quais ele estava refletindo, inquietações e que nesse movimento da vida, não eram essencialmente sobre História Antiga, mas sobre como a História Antiga era lida, principalmente no Renascimento. Quando eu entrei em contato com os textos mais antigos dele, escritos no final da década de 1990, principalmente "A retórica do método" ${ }^{1}$, em que ele trabalha o discurso fúnebre do Tucídides, achei é maravilhoso. Eu já tinha feito algumas matérias na Letras, estudado um pouco de grego, então, eu li, foi meio... Daí eu já tinha vontade de pesquisar, ali para 2004, 2005, se eu fizesse o mestrado seria legal. Aí eu comprei o livro do Ginzburg, nas feiras do livro, não foi nem essa do final do ano, acho que foi uma da FEA [Faculdade de Economia, Administração, Contabilidade e Atuária]. Trabalhava justamente a prova e a história, com a retórica do Aristóteles. Aquele texto mexeu muito comigo, com questões de como você constrói a prova com relação a retórica, o reaproveitamento da retórica antiga. Eu já tinha lido o texto do Francisco, daí eu procurei.

Revista Epígrafe: O mestrado foi sua primeira experiência com pesquisa acadêmica, mesmo?

Carlos Ogawa: Sim, sim. Eu acho que se eu tivesse feito iniciação científica o mestrado teria sido mais fácil. Há um aprendizado durante a pesquisa. A elaboração do meu primeiro projeto foi muito sofrida, e a primeira versão foi negada pela FAPESP [Fundação de Amparo à Pesquisa do Estado de S. Paulo], com razão, pois realmente o

\footnotetext{
1 PIRES, F. Murari. A retórica do método (Tucídides I.22 e II.35). Revista de História, São Paulo, n. 138, pp. 9-16, junho/1998.
} 


\section{entrevista|}

Carlos Ogawa

projeto estava inadequado. Consegui na segunda tentativa. O Francisco é uma pessoa maravilhosa e me apoiou durante todo o processo.

Revista Epígrafe: Aí, bom, você terminou o mestrado e decidiu não seguir carreira acadêmica, pelo menos naquele momento. O que te levou a fazer essas outras escolhas?

Carlos Ogawa: Ah, o mestrado foi muito sofrido... [risos]. Eu fiquei meio de bode, alguns meses sem ler. "Não quero ler e não quero escrever", dizia na época. Eu fui dar aula, eu consegui emprego numa escola perto do metrô Santa Cruz. Eu queria fazer o doutorado, mas o Francisco me disse, antes mesmo de eu começar o mestrado: “Olha, você quer fazer o mestrado comigo, ótimo, mas eu não vou levar o doutorado para frente porque eu quero me aposentar". E ele sempre foi muito claro: "Quero me aposentar mesmo!"; tipo “Não quero me aposentar e continuar aqui na pós [graduação]"; fechar a lojinha [risos]. Ele sempre foi muito claro. Foi legal porque dava uma urgência para a pesquisa, mas também quando terminou o mestrado, a continuação perdeu um pouco de sentido. Aquela experiência ali meio que se fechou, eu não sabia muito bem o que pesquisar, eu teria que procurar outro orientador... E eu estava lá na escola. No ano seguinte, me chamaram para um processo seletivo em uma editora, eu me inscrevi, mandei o e-mail com o currículo, eles estavam contratando, acabei passando. Eu terminei o mestrado em 2010 e em 2011 eu já estava trabalhando numa editora, eu fui sugado.

Revista Epígrafe: Nesse meio tempo, você trabalhou com outra coisa na área de História? Você falou que deu aula... A gente viu no seu currículo que você trabalhou em arquivo por algum momento. O que você fez nesse meio tempo, antes de entrar 


\section{entrevista}

O aprendizado de um ofício ou um caminho pelos livros didáticos

para trabalhar na editora?

Carlos Ogawa: Na verdade, o trabalho em arquivo foi durante a graduação ainda, foi uma bolsa da reitoria. Eu acho que foi uma experiência... Eu acho que foi a experiência mais definidora da profissão. Várias peças se juntaram na cabeça sobre o que é o trabalho do historiador, sobre o trabalho com fontes, sobre patrimônio. Quando eu me deparei com o arquivo é que algumas peças se juntaram, os aprendizados da graduação. Você vê as experiências das pessoas registradas e concretizadas ali em uma organização dada por uma instituição. Quando olhei, dia a dia, as fichas de inscrição dos cursos de Saúde Pública, você vê as pessoas se inscrevendo e escrevendo porque elas querem fazer aquilo por 10 ou 20 anos, e você vê a continuidade dos relatos, a riqueza daqueles registros, então isso faz você entender bem a profissão, a importância. Ou mesmo os trabalhos mais banais, coisas que existiam lá nos dossiês de funcionários, que os funcionários mandavam o convite de casamento para comprovar licença gala, você vai lendo isso em série. É muito interessante. Então essa experiência em arquivo foi maravilhosa, era o arquivo da Faculdade de Saúde Pública. Era um arquivo que não tinha sido organizado até então, pelo menos não de acordo com a tabela de temporalidade da USP, e era um arquivo que estava mal acondicionado. Nós fomos tateando, pedindo ajuda para o Arquivo Central da USP. Foi uma experiência bacana, mas, assim, a formação aqui não foi muito direcionada para isso. Depois a professora Ana Maria Camargo deu cursos de arquivologia aqui, isso foi sei lá, uns dois, três anos depois que eu me formei. Eu ainda consegui fazer o curso de Museologia com o Paulo [César Garcez Marins]. O Departamento começou a trazer uns professores do Museu Paulista e do IEB [Instituto de Estudos Brasileiros] para dar optativas aqui, porque as pessoas não conseguiam se formar, porque não tinha optativas. E algumas experiências bacanas 


\section{entrevista|}

Carlos Ogawa

surgiram, mas não era considerado como parte essencial do trabalho do historiador.

Revista Epígrafe: Você fez a licenciatura?

Carlos Ogawa: Sim, era bem mais simples que hoje em dia. Atualmente, há muito mais créditos suplementares. Eram só 20 horas de estágio para as disciplinas menores e 40 para as Metodologias [do Ensino de História], dava para fazer em um ano e meio e só. Era uma estrutura bem... simples e ainda assim interessante. Acho que depois, com o trabalho na editora, acabei fazendo muitas das leituras que eu poderia ou deveria ter feito naquela época. Aliás, havia a discussão sobre trazer a licenciatura para dentro do Departamento, não sei se ela ainda existe, aí abriram uma disciplina aqui relacionada. Eu acho que seria uma experiência interessante pensando retrospectivamente, do ponto de vista do currículo.

Revista Epígrafe: Entrando no assunto do mercado editorial, quando você entrou para trabalhar, você falou que mandou o currículo e entrou. Como foi essa primeira experiência? O que levou primeiro a querer trabalhar com isso, se é que foi um querer?

Carlos Ogawa: Bom, tinha um lado pessoal, o meu pai já tinha trabalhado em editora, mas não no editorial. Eu sempre soube que era corrido, que era muito intenso, mas que também remunerava bem. Como professor, eu ganhava mais ou menos o mesmo que a bolsa FAPESP, R\$1200,00 em 2010 e R\$1350,00 como professor. E a editora oferecia mais que o triplo disso, claro, com 44 horas semanais - eu não dava as 40 horas semanais como professor. Eu também fui atraído pela mística de fazer um livro, que hoje se perdeu [risos]. E era para trabalhar com livros de História, e eu 


\section{entrevista}

O aprendizado de um ofício ou um caminho pelos livros didáticos

pensei na época que seria uma forma de não perder a ligação com as experiências anteriores, de continuar trabalhando com a disciplina, com um campo do conhecimento que eu gostava, com um tema que me é muito caro. Eu embarquei.

Revista Epígrafe: Já era com livro didático ou você trabalhou com livros acadêmicos, livros de divulgação? Foi na [Editora] Moderna?

Carlos Ogawa: Foi na Moderna. Em 2011, eu comecei na Moderna e sempre com livros didáticos. Eu só trabalhei com livros que não são didáticos por fora, em alguns intervalos de trabalho, mas é sempre muito corrido, então eu não pego muitos trabalhos freelancers. Essa experiência na Moderna, assim como as demais, sempre foi muito agitada, a carga de trabalho era, no começo, muito penosa, os prazos curtos. Havia um aprendizado, porque fazer um livro é um ofício, um ofício novo, por mais que seja um livro didático de História, tem todo o processo de edição, de realmente fabricar o livro - e não estou nem pensando do ponto de vista da autoria mas realmente como você transforma um arquivo Word num objeto impresso. Então há um oficio aí, e foi um longo aprendizado.

Revista Epígrafe: Você começou com livros de um segmento específico, [ensino] fundamental, ensino médio?

Carlos Ogawa: Sim, eu comecei com coleções para os anos finais do ensino fundamental, primeiro para o mercado, que são as escolas particulares, mas logo em seguida passei para o PNLD [Plano Nacional do Livro Didático] 2014. Participei de todos os PNLD seguintes, exceto o PNLD 2020. O número do PNLD é sempre a data de entrada do livro na escola. Então, eu fiz o PNLD 14 em 2011 e 2012, porque o livro 
entra na escola em 2014.

Revista Epígrafe: E como é o processo do PNLD?

Carlos Ogawa: Ele mudou bastante nos últimos anos, mas essencialmente ainda é o mesmo. As editoras vendem os livros em grande quantidade para o governo e o governo compra esses livros a preços mais baixos - muito mais baixos. Um livro que no mercado custa $R \$ 150,00$, o governo compra por $R \$ 15,00, R \$ 10,00$; no caso do ensino médio e dos anos finais do ensino fundamental, cada volume impresso era reaproveitado por 3 anos. É uma política da época do Fernando Henrique, mas é uma política pública boa. Ainda mais se você reparar que até os anos 2000 não havia difusão de informações via internet. Então, efetivamente, era o jeito que o conhecimento disciplinar podia chegar fisicamente à escola. Hoje os livros não são mais necessários do ponto de vista da informação, porque o professor tem autonomia, ele pode estruturar um curso com sua bibliografia, há muito material disponível. Quando o programa foi estruturado na década de 1990 não era assim, era um mundo pré-internet ainda, a internet não tinha a capilaridade que tem hoje.

Quando governo lança o edital, as editoras se inscrevem, não é o governo que procura as editoras. Embora o governo pague um preço considerado até baixo por volume, o programa ainda rende muito dinheiro - hoje o gasto com o PNLD é de 1 bilhão por ano, então é muito dinheiro.

Esse é o funcionamento do programa, o governo abre um edital, há uma série de itens nele, mais 90 páginas. O edital é aberto caso vocês queiram consultar - acho até interessante para vocês entenderem como funciona uma política pública de educação no Brasil. E tem exigências, como "tem que estar isento de erros de revisão”, "pluralidade de opiniões”. Antes da BNCC [Base Nacional Comum Curricular] 


\section{entrevista}

O aprendizado de um ofício ou um caminho pelos livros didáticos exigia-se para os livros de História, por exemplo, "não ter anacronismo", "não pode voluntarismo", sabe, "erros de data", "erros de informação". É bem interessante. O PNLD ajudou a dar forma aos livros de todos os componentes curriculares, porque o livro do PNLD é normalmente lançado no mercado em seguida. Ele era feito para o PNLD, para atender às exigências do edital, e relançado no mercado para escolas particulares, como forma de rentabilizar todo o trabalho. Como o processo de avaliação demora um ano, dá tempo para lançar no mercado como novidade. Mas é isso: o governo compra, passa por uma avaliação pedagógica, a avaliação pedagógica diz quais livros foram aprovados, passa os relatórios para as editoras, os relatórios podem ser contestados e tal, mas normalmente os recursos não são bem sucedidos. Aí, ocorre um processo de negociação: quanto maior número de livros, menor o preço por volume.

Os livros são escolhidos pelos professores e coordenadores, pelo menos quando as boas práticas são adotadas. O professor entra no sistema do MEC [Ministério da Educação], o SIMEC [Sistema Integrado de Monitoramento Execução e Controle], ele vai lá e escolhe a coleção que julga mais adequada para a sua prática de ensino e as editoras ficam responsáveis pela distribuição desses volumes para as escolas. Isso, claro, causa um gargalo, porque para você ter um sistema de distribuição, você precisa ser uma grande empresa; então, por um lado o PNLD barateou o preço do livro didático para o governo, mas também favoreceu a concentração de capital nas empresas.

Revista Epígrafe: E a produção do livro em si, como funciona?

Carlos Ogawa: Bom, eu falei que é um ofício, mas é um ofício com práticas muito variadas. Já trabalhei em várias casas [editoriais] - já trabalhei na Moderna, na 


\section{entrevista|}

Carlos Ogawa

[Editora] Saraiva, na SM [Educação], e agora eu estou na Somos [Educação], e em cada uma dessas casas editoriais o processo é diferente; o percurso é parecido, mas o processo é diferente, que vai desde o original de texto até o fechamento do PDF. No meu trabalho como editor, acompanho até o fechamento do PDF. Eu já trabalhei em obra coletiva e em obra autoral; no caso da obra autoral, o autor tem uma proposta de coleção, uma proposta de obra e ele manda para ser avaliado para a editora, ou então a proposta já está aprovada porque é uma reedição e ele faz só um plano de reedição e envia os originais com as alterações que ele quer; e, no caso da obra coletiva, existe um projeto de coleção e esse projeto é propriedade da editora.

Revista Epígrafe: E na Moderna você era esse editor especialista?

Carlos Ogawa: Sim. Ainda continuo sendo, mas ao longo do tempo eu fui ganhando experiência na profissão. Antes eu me identificava como um historiador que edita; hoje eu estou tão longe da academia que eu me sinto muito mais editor que historiador, e não conseguiria me sentir diferente, porque eu passo mais de 10 horas por dia fazendo isso. Mas eu ainda continuo tendo bastante contato com a disciplina, porque eu tento acompanhar as pesquisas acadêmicas, mas sei que não estou mais inserido nesse ambiente de produção do conhecimento. E esse é outro ponto: o principal objetivo do livro didático não é produzir conhecimento a respeito da disciplina, pelo menos não dentro das editoras; é um espaço de mediação. As escolas produzem conhecimento, a academia produz conhecimento e as editoras mediam. E essa mediação sofre impacto das práticas de mercado da sociedade em que vivemos, das pressões sobre a produção - de prazos, orçamentos etc. Há uma série de condicionamentos. Aliás, quando avaliam um livro didático, eles sempre olham o produto final como se houvesse uma intencionalidade em tudo que está escrito, e na 


\section{entrevista}

O aprendizado de um ofício ou um caminho pelos livros didáticos verdade não, porque a produção de um livro é cheia de percalços, obstáculos, e nem sempre há uma intencionalidade. Assim como todo texto, eu imagino. Por exemplo, quando vocês escrevem um texto, um artigo, vocês sabem que não há uma intencionalidade em absolutamente tudo que vocês fizeram. Muitas vezes, quem não participa do processo de produção não consegue ver essas frestas, lacunas, vê só o produto acabado, como se fosse uma casca de ovo, lisinha, mas é claro, como todo produto humano, tem seu processo produtivo que nem sempre é organizado de forma intencional.

Revista Epígrafe: Voltando para a questão do processo, você falou que há a submissão do autor, mas e depois disso? Aliás, a editora procura os autores ou os autores procuram as editoras?

Carlos Ogawa: Depende. A editora pode decidir que precisa de uma obra nova no catálogo e procura autores - e na verdade esse é o processo mais comum, porque a produção é muito cara, costuma passar de 1 milhão de reais. Mas também há casos de um autor, com uma ideia bacana, procurar uma editora. É raro, mas acontece. Porque esse livro, mesmo depois de terminado, vai para o divulgador, que vai na escola; tem um assessor pedagógico que estuda as coleções para atender aos professores. Tem toda uma cadeia do livro que vai até a porta da escola. Isso não acontece com um livro que não é didático: ele é mais com os agentes que vendem com as livrarias, com publicidade. Inclusive, é raro propaganda com livro didático, isso só acontece em época de escolha do PNLD. É um produto que tem um tipo de venda muito específico, mas que traz com ele uma cadeia de profissionais muito grande.

Há perfis de época: até a década de 1990 muitos professores escreviam livros didáticos, professores de escola particulares renomadas; depois, na época de 


\section{entrevista|}

Carlos Ogawa

2000/2010, muitos professores universitários assumiram a autoria. Vários professores daqui [da USP] são professores de livros didáticos: só de cabeça lembro do Flávio de Campos, que escreveu com o Júlio [Pimentel]; o José Antonio [Vasconcelos] é autor de um livro de Filosofia para a SM; o José [Alves de Freitas] Neto, da UNICAMP [Universidade Estadual de Campinas], que é um dos autores da Base [Nacional Comum Curricular], é autor de um livro didático pela Harbra. Ao longo do tempo, o perfil do autor de livro didático e quem as editoras convidavam para elaborar o livro mudou.

Revista Epígrafe: E hoje em dia, como acontece esse convite por parte das editoras? Ainda é para professores universitários?

Carlos Ogawa: Mais ou menos. Hoje a gente está em um período de mudança por causa da Base, principalmente a Base do ensino médio. Provavelmente teremos obras por área do conhecimento no próximo PNLD², e não mais livros de História, e sim de Ciências Humanas e Sociais Aplicadas. Então, inúmeras transformações estão ocorrendo, é um período bem incerto. Nesse momento, podem surgir coleções de pessoas que simplesmente submeteram uma proposta boa, ninguém sabe como serão as obras por área. Vão aparecer propostas novas com conjuntos muito diversos, eu imagino, autores muito experientes que resolvam tentar. Há casos de professores de escolas particulares que estão propondo trabalhos com metodologias ativas, o governo também está exigindo isso, então as editoras estão voltando a entrar em contato com professores de escolas particulares e ver qual dessas experiências pode se transformar em livros didáticos. Então a situação é bem incerta, não dá para dizer que teremos o mesmo perfil que tivemos nos últimos dez anos.

\footnotetext{
${ }^{2}$ Como a entrevista foi realizada em 2019, vale destacar que isso de fato ocorreu.
} 


\section{entrevista}

O aprendizado de um ofício ou um caminho pelos livros didáticos

Revista Epígrafe: E aí a gente volta... O livro chegou, foi escolhido...

Carlos Ogawa: É, na verdade é uma proposta. Chega uma proposta de livro que é mais ou menos... É que no caso de História, os livros eram muito parecidos entre si e esse foi um dos efeitos do PNLD. Então, as coleções eram todas cronológicas e integradas, começavam na Pré-História e terminavam no mundo contemporâneo. Nas coleções de anos finais do ensino fundamental, a partir do volume 7 começam a alternar capítulos de [História do] Brasil e História Geral. De qualquer forma, há uma proposta de autor que é avaliada, uma proposta de sumário, e a editora avalia primeiro se aquilo tem consistência, se pela experiência dela os professores vão aceitar - os livros também não mudam porque o professorado é muito conservador, não do ponto de vista político necessariamente, mas da estrutura e de variedade de propostas didáticas, principalmente em História. Coleções com sumários muito diferentes entre si atrapalham os professores que lecionam em escolas diferentes. $E$, além disso, se a editora percebe que determinado formato vende mais, ela vai querer direcionar as coleções para adotar aquele formato.

Uma vez aprovado, o autor começa a elaborar os originais, isso vem formato Word; quando chega, passa para um editor, que primeiro elabora um projeto editorial. A gente edita um capítulo modelo, manda para o setor de design, que faz o projeto gráfico da coleção. Em seguida, passa-se ao projeto visual do capítulo modelo: se vai ter um boxe; se esse boxe vai ter um fio; se vai ter um corpo diferente para texto citado; se vai ter um bullet do lado do número da atividade ou não; se a atividade vai ser em número romano ou não; se vai ter recuos... Há uma série de detalhes visuais. Por fim, o material volta para o editor, e os coordenadores, gerentes e diretores, aprovam ou propõem alterações; negociam alterações com o autor até o 


\section{entrevista|}

Carlos Ogawa

modelo ficar pronto. Enquanto isso, o autor vai escrevendo. Entre as tarefas do editor está garantir que os originais se encaixem no projeto editorial. Se o autor fez uma proposta de coleção em que uma seção tem que ter uma página inteira, se o autor, por qualquer motivo, escreveu só meia página, o editor vai lá e devolve. Se um capítulo está muito curto, se o autor esquece algum conteúdo... Quando o autor escreve, em muitos casos ele não pensa nessas questões, só escreve e entrega. Esse é o processo de edição, é um processo de diálogo entre autor e editor, que é um processo bem rico, porque é um exercício de alteridade para os dois, porque às vezes o autor quer que a vontade dele prevaleça e o editor precisa conciliar as demandas de prazos, do processo produtivo com aquilo que o autor deseja.

Também é responsabilidade do editor pedir e acompanhar os elementos que acompanham o texto do autor, como fotografias, mapas, ilustrações... E, depois das exigências do PNLD, passamos a alertar autores sobre a importância de representar a diversidade da população brasileira. Nossos fornecedores já passaram a incluir, entre as opções de fotos, negros e indígenas, o que é positivo. Antigamente, era comum pedir produção para representar uma família negra em um parque de diversões. Essas fotos não existiam, encontrávamos só famílias brancas. Ou com casais heterossexuais. Então tinha que contratar um fotógrafo e uma família para conseguir a foto que você precisava e ter diversidade racial ou sexual no livro. Hoje, os bancos melhoraram nesse sentido, não só para os livros didáticos, mas também para publicidade.

Outro elemento que, normalmente, os autores não fazem são os infográficos. O autor normalmente não sabe quais recursos estão à disposição dele, às vezes é o editor que fala qual ilustração é possível, por exemplo. Às vezes ele quer uma foto da acrópole de Atenas ou da ágora de Atenas, mas só tem ruínas, então não dá para ver como era. Mas se você faz uma ilustração com fontes confiáveis, dá para fazer, só que 


\section{entrevista}

O aprendizado de um ofício ou um caminho pelos livros didáticos aí é o editor que faz os pedidos, com critérios, referências, fontes e depois confere o trabalho do ilustrador. O autor confere a ilustração em estágios mais avançados. Às vezes você tem que conferir coisas mais bestas, como cinco dedos na mão [risos], ou se o prédio foi feito na proporção correta... É isso. A gente lida no original com todas essas demandas, faz os pedidos de autorização de textos. Para revistas e livros é mais tranquilo, mas para poemas e músicas o risco de recebermos uma resposta negativa é considerável. Ou então é muito caro. Já aconteceu comigo com um samba. A autorização estava demorando muito e o processo editorial chegando ao fim, os prazos também, e, na última etapa de checagem do livro, o herdeiro do sambista pediu um valor muito alto. Precisamos trocar a música três ou quatro dias antes da entrega.

Revista Epígrafe: E é sempre pago? Sempre precisa pagar esses textos? Precisa pagar direitos autorais, não é?

Carlos Ogawa: Para livros e artigos científicos, a lei não explicita o tamanho, fala de pequenos trechos; se é um livro de 300 páginas e você usa três parágrafos, a lei te dá cobertura para não precisar pedir autorização ou pagar direito autoral para o autor, porque é direito de citação. Porém, para poesia, letras de música, e dependendo do autor, é bem caro. Há casos de $\mathrm{R} \$ 5.000,00, \mathrm{R} \$ 10.000,00, \mathrm{R} \$ 20.000,00$. Para livros de Língua Portuguesa, isso é muito importante, porque eles lidam com gêneros literários - e é até meio cruel - porque o autor escreve um capítulo baseado em um gênero, centrado em uma poesia, e aí o detentor do direito autoral recusa e precisa refazer o capítulo. E aí outros textos já foram comprados ou que já têm autorização, as fotos também... 


\section{entrevista}

Carlos Ogawa

Revista Epígrafe: Quanto tempo mais ou menos dura o processo?

Carlos Ogawa: Depende. Se é uma reedição, pode durar sete ou oito meses. Há produções muito peculiares. Eu já trabalhei em uma produção que durou quase dois anos, de tantas idas e vindas. Outro caso foi que a empresa não queria que a obra fosse alinhada à BNCC, quando ainda não estava aprovada. A gente estava na segunda prova, o que é mais ou menos uns $60 \%$ da coleção pronta, e eles mudaram de ideia. E aí volta para o original. Então, depende muito da complexidade do trabalho e do que acontece no caminho. Se for só uma adaptação para o mercado de um livro editado para o PNLD, aí é mais simples, aí dá para fazer em 2 ou 3 meses. Há casos em que o autor some: “Estou estressado, estou trabalhando demais, tchau” [risos]; há casos em que a editora desiste no meio do caminho e paga uma quantia para o autor.

Revista Epígrafe: Você disse que cada editora tem a sua especificidade. Você conseguiria falar um pouco sobre isso?

Carlos Ogawa: Há editoras que prezam por obras coletivas - e essas informações são públicas, se você entrar no site da Moderna vai ver que tem o Araribá, o Pitanguá, enfim, não é nada escondido. Na Moderna, por exemplo, quando você trabalha numa obra coletiva não tem etapa de validação autoral, mas por outro lado pode ter uma etapa de preparação, que é mais intensa. O preparador é um profissional que olha mais pra redação; o editor não, geralmente ele vê um pouco de língua portuguesa, de construção da frase, construção do parágrafo, coerência e tal. Mas o preparador fica ali na linguagem, adequação da linguagem, no padrão editorial. Algumas editoras têm um processo mais analógico, em papel, outras têm um processo mais digital.

Até pouco tempo atrás eu fazia prova em papel. A prova é a primeira etapa de 


\section{entrevista}

O aprendizado de um ofício ou um caminho pelos livros didáticos checagem do material depois que ele é diagramado: volta para o editor de arte, passa pela revisão, aí o editor valida ou não as marcas, os apontamentos da revisão e vê as inequações de todo tipo; se está faltando texto na página, se há sobra texto, se a foto está pequena, se há informações, conceitos que precisavam estar presentes no original, às vezes uma atividade não tem o comando correto, a resposta não está de acordo com a pergunta... Atualmente, a maior parte das editoras trabalha com prova em PDF, mas depende muito também do caráter da produção. Às vezes, para uma adaptação mais simples, a gente não volta para o Word. Já trabalhei numa produção que não valia a pena você voltar para o Word, então eles pegaram a edição anterior, imprimiram cada página em folhas A3, e a gente fez as marcações ali, e o editor de arte fez a versão final. Então, depende muito do tipo de produção, depende muito do livro também. Há coleções que podem ser separadas em pedaços. Livros com remissões dão muito trabalho. A remissão é a indicação da página em que cada conteúdo está; se isso faz parte do projeto editorial, se o autor usa isso com muita frequência, você tem que definir a paginação no início do trabalho. Se há inclusão de conteúdos e de páginas, todas as remissões precisam ser verificadas novamente.

Revista Epígrafe: Normalmente os livros didáticos tem a parte do texto e tem a parte das atividades. Como é esse processo de pensar a atividade?

Carlos Ogawa: De fato, as atividades estão ganhando cada vez mais importância nos livros didáticos. Antigamente, os professores faziam uma atividade que era principalmente retomadas de conteúdo; depois, com os PCN [Parâmetros Curriculares Nacionais], e agora com a Base, o consenso é que o objetivo da escola [e do livro didático] não deve mais transmitir conteúdos, e sim trabalhar habilidades e competências, e, para isso, as atividades às vezes são mais importantes que o 


\section{entrevista|}

Carlos Ogawa

conteúdo em si. Então, não é simplesmente narrar a Revolução Francesa e a Revolução Inglesa, mas comparar; o fato de comparar é mais importante do que descrever as duas revoluções. Agora com a Base, há um checklist de habilidades e competências para aprovação dos livros no PNLD: “Habilidade tal foi contemplada em tal página"; “Habilidade tal foi contemplada em tal página”. Antes, as atividades eram feitas com base na experiência acumulada dos professores, e as editoras sempre contratavam os professores para elaborar as atividades. Hoje, temos que atender à BNCC.

Há padrões editoriais para estruturar um comando de atividade, e alguns caminhos que sabemos que não funcionam: se o comando de uma atividade é muito longo, a chance de não ser claro é grande. O comando não pode ser vago também. Para ajudar, segmentamos as atividades, em A, B, ou C, por exemplo. Refinamos o comando para deixar evidente o que precisa ser feito: identifique, ordene, analise, descreva, reflita... Espera-se que o professor trabalhe primeiro as retomadas de conteúdo e depois a reflexão, para que haja um aumento de complexidade; debater é mais complexo que retomar.

Revista Epígrafe: E já aproveitando essa questão da Base, como que ela impactou o trabalho editorial? Provavelmente todas suas práticas tiveram que ser revistas no momento que a Base foi aprovada...

Carlos Ogawa: As práticas editoriais e a confecção do livro nem tanto, mas houve, sim, um trabalho de convencimento dos autores que discordavam da Base, muitas vezes com razão - ok, você quer fazer um livro que não alinha com essa Base. A de História foi, junto com a de Língua Portuguesa, as mais problemáticas, então há problemas de conteúdo, na redação das habilidades. Para vocês verem que os processos históricos 


\section{entrevista}

O aprendizado de um ofício ou um caminho pelos livros didáticos

não são uniformes: quando nós vimos as primeiras versões da Base, que tinha uma seleção de conteúdo muito voltado para História Indígena, História Africana, vimos que alguns professores, principalmente os de escolas públicas, viam a base positivamente; as escolas particulares, por outro [lado], não iam topar. Houve uma celeuma, não sei se vocês acompanharam. A versão que temos hoje não é tão inovadora quanto a anterior, porém, a partir de outubro do ano passado, a Base ficou maravilhosa. A situação política do país, com as tentativas de descrédito do conhecimento científico, se agravou tanto, que a gente nem reclama mais. É um alívio ter uma lei que diz que os editais do PNLD devem seguir a Base - olha que coisa maluca, é uma lei do [Michel] Temer, de 2017.

Revista Epígrafe: E como é a produção do material do professor?

Carlos Ogawa: O manual do professor geralmente tem uma parte comum e uma parte específica. A parte comum descreve para o professor os princípios didáticos, a relevância dos estudos históricos para a cidadania, um histórico do ensino da disciplina nos últimos 40 anos e lista as principais escolas historiográficas. A gente usa muito [Roger] Chartier, [Peter] Burke para a questão cultural, por exemplo, Escola dos Annales pra falar de documento.

Revista Epígrafe: E isso é o autor que produz também?

Carlos Ogawa: É, o autor ou a editora, se for uma obra coletiva. E também tem a parte específica, em que há comentários, normalmente a reprodução do livro do estudante com alguma anotação só para o professor. Pode ser comentários como: "Professor, chame atenção dos alunos para este conceito"; ou "Na resolução dessa atividade, leve 


\section{entrevista}

Carlos Ogawa

em consideração A, B ou C". Para os anos iniciais do ensino fundamental, quando se trabalha com o tema da família por exemplo, é normal orientar sobre a composição familiar dos estudantes, para o professor ter sensibilidade. Há também as respostas e propostas de atividades; ou, então, como o professor pode desdobrar a atividade do livro em outra em sala, por exemplo, trabalhando ocupação do território brasileiro você pode fazer uma atividade interdisciplinar com Geografia. É possível estabelecer esse diálogo com o professor para que ele tenha mais recursos.

E, assim, com qual critério, de onde vêm essas orientações? Bom, muitos autores têm experiência em sala de aula e também as editoras costumam recorrer a leituras críticas. Às vezes o autor não tem experiência com História da África, mas a coleção precisa de materiais sobre esse assunto. A editora solicita uma leitura crítica para um professor universitário para que ele indique os problemas, faça comentários, indique bibliografia complementar. O editor repassa a leitura para o autor - às vezes o editor precisa fazer intermediar, porque as críticas foram muito contundentes. É a mesma coisa com as atividades. Muitos editores já foram professores, há casos de pessoas que trabalharam por 20 anos em sala de aula e acabam trabalhando com a gente na editora. Há sempre uma circulação de saberes entre editoras e professores, que vai desde o SAC [Serviço de Atendimento ao Consumidor] - os professores escrevem até com frequência para as editoras para apontar erros - até a leitura crítica. Ultimamente surgiram reclamações para dizer que na tal da Nova Era não tem que ter esse tipo de conteúdo no livro, pai de aluno também... Aliás, uma das reclamações desse tipo era de uma professora de História.

Revista Epígrafe: Carlos, agora alguns livros didáticos vêm acompanhados de CDs... Tudo bem que CD não é uma coisa exatamente moderna, mas que tem sites que você pode acessar e ter um conteúdo complementar. Como que funciona essa 


\section{entrevista}

O aprendizado de um ofício ou um caminho pelos livros didáticos informatização do livro didático? Esse site que o professor pode acessar, que tem questões, respostas, planos de aula... Essa parte é com você também?

Carlos Ogawa: Olha, depende da editora. Tem editora que tem um setor específico que cuida de todas essas questões; há editoras que não cuidam muito disso, às vezes terceirizam; ou, ao contrário, trazem todos esses materiais para o editorial fazer. Quando a mesma equipe que fez a coleção impressa também faz o conteúdo digital, dá para garantir que o conteúdo digital tenha a mesma cara do livro; agora, se foi feito externamente e as pessoas que trabalharam no livro ou o autor têm pouco contato com esse material, sai um pouco diferente. A decisão é tomada com base em custos, porque o livro, de forma geral, é mercadoria, é importante lembrar. A relação do impresso com o digital se tornou semelhante à que existia nos jornais na década de 2000, e isso se reflete também na pressão sobre mão de obra, demissões...

Agora, o modelo que tem prevalecido para conteúdos digitais é o da assinatura, como se fosse um streaming de serviços educacionais: você tem um livro em formato impresso, sim, o livro tradicional, mas também tem uma versão digital, tem plataformas adaptativas, os conteúdos digitais, tutor... Enfim, uma série de serviços que são ofertados. As plataformas adaptativas oferecem estatísticas de progresso: "Quantos alunos na sala do professor $X$ acertaram as perguntas relacionadas à habilidade 33 da base". Isso já é possível, essas informações já são quantificáveis. Daria um bom estudo, é sério, porque você pode transferir uma série de tecnologias sociais que antes estavam no âmbito empresarial para a escola. Tanto o aluno, quanto o professor, os gestores escolares, os pais conseguem metrificar os desempenhos. Não estou dizendo que é bom. Uma coisa que acontece nesse mundo virtual é que o seu comportamento gera informações e que essa informação, de alguma forma, é utilizada, quantificada, o que eles chamam de Big Data. As editoras 


\section{entrevista|}

Carlos Ogawa

que têm essas plataformas conseguem, por exemplo, quantificar quantos alunos acertaram a questão nove da coleção X no Estado de São Paulo. No mundo da educação não é mais simplesmente uma lousa sofisticada. Não tenho acesso a isso, mas nos próximos anos o desempenho dos estudantes vai ser usado como informação de mercado. Seria bom que a academia prestasse atenção a esse fenômeno.

Revista Epígrafe: Não tem muitas escolas públicas que estão adotando esse formato digital, ou já tem um crescimento nessa área?

Carlos Ogawa: Não, porque no caso do PNLD é mais tradicional, o governo paga principalmente pelo impresso. O governo, nos últimos anos, passou a exigir sequências didáticas, projetos integradores, itens de avaliação, mas mesmo o que eles chamam de materiais digitais são PDFs para o professor.

Há prefeituras que decidem não aderir ao PNLD e fazer uma licitação para sistemas de ensino, se não me engano com o dinheiro do FUNDEB [Fundo de Manutenção e Desenvolvimento da Educação Básica], o que está dentro da lei. A prefeitura consegue com que a editora forneça serviços pedagógicos, tutoria, plataforma... Aliás, os sistemas de ensino são mais voltados para atender as avaliações padronizadas, que é outro ponto bem crítico da educação nos nossos dias.

Revista Epígrafe: Mesmo o Enem [Exame Nacional do Ensino Médio]...

Carlos Ogawa: O Enem, gente, eles têm um controle assim, viu? Eles cruzam os dados socioeconômicos com o desempenho dos estudantes. Quem mostrou isso foi a Janice Theodoro, que era professora de América Colonial [na USP] e foi uma das 


\section{entrevista}

O aprendizado de um ofício ou um caminho pelos livros didáticos

elaboradoras da versão da BNCC que foi homologada. Numa das palestras a respeito da Base, ela mostrou que alunos da classe C e D não conseguem resolver determinado tipo de atividade, então, sim, o governo também tem esse tipo de cruzamento no Enem.

As provas padronizadas são meio que o termômetro da educação, porque elas integram a nota do IDEB [Índice de Desenvolvimento da Educação Básica] e o desempenho do país no PISA [Programa Internacional de Avaliação de Estudantes]. Isso não quer dizer que é uma educação melhor, uma educação que transforma as pessoas em mais felizes, mais plenas, mas é o que as editoras e os organismos públicos medem como em termos de eficiência, e essas avaliações padronizadas têm efeito na elaboração de materiais didáticos.

Revista Epígrafe: Os materiais didáticos estão sendo feitos para condicionar o aluno a resolver essas avaliações padronizadas?

Carlos Ogawa: É, condicionar é uma palavra muito forte, talvez direcionar... É uma série de questões que são complexas, porque a situação do Brasil é de penúria, então você tem algumas regiões do Brasil em que o IDEB é muito baixo - e, sim, o IDEB é um instrumento importante pra você tentar avaliar, mas por outro lado, claro, não dá para avaliar a educação só em termos de eficácia nos testes padronizados. A gente não deve educar as pessoas para serem eficazes em provas, e sim para buscarem a realização pessoal, afetiva, profissional. Retomando, as avaliações têm influência na elaboração não só dos materiais didáticos, mas das políticas públicas de educação no Brasil, então é uma forma de você também direcionar o dinheiro que vai pra educação. Toda vez que se divulga o IDEB, todas as pessoas envolvidas com a educação, seja como política pública, seja como negócio, se mobilizam para analisar 
os resultados. É um acontecimento.

Revista Epígrafe: Você fez algum curso para melhorar suas habilidades enquanto editor, algum curso de especialização em edição?

Carlos Ogawa: Existe o curso de graduação em editoração, que é muito bom, mas é um curso voltado para vários tipos de publicação: edição de revista, livros... Há colegas de trabalho formados em editoração, mas eles não são tão comuns. Há muitas pessoas formadas em Letras e muitas delas começaram como revisoras. Há também os editores especialistas, principalmente de Matemática.

Há cursos de especialização na Universidade do Livro da UNESP [Universidade Estadual Paulista], como o de produção editorial, o de preparação e revisão, o que ensina a fazer textos de quarta capa, ou então alguns mais voltados para a área de Marketing. Mas muito do trabalho é aprendido no dia a dia, com pessoas mais experientes, ou então resolvendo problemas. Há muito aprendizado na prática do ofício, embora esse lado artesanal esteja meio que sumindo. Aliás, esses cursos estão surgindo justamente porque as pessoas estão aprendendo menos dentro das editoras, porque está cada vez mais corrido, com menos tempo para formação. Por fim, há uma pós-graduação em Produção Editorial na Casa do Saber, e tem uma parte dedicada ao livro didático.

Revista Epígrafe: E quando foi, mais ou menos, que você fez esses cursos?

Carlos Ogawa: Foi logo no começo... 2011 até 2013. E depois eu tive períodos em que eu tive prazos muito curtos, produções muito difíceis e tal. Então eu meio que não tinha tempo mesmo; cheguei a trabalhar, sei lá, 60 horas por semana... Aí não deu 


\section{entrevista}

O aprendizado de um ofício ou um caminho pelos livros didáticos

para fazer mais, né? [risos].

Revista Epígrafe: Bom, você é um historiador que foi trabalhar na área do mercado editorial. Como você vê a contribuição da sua formação em História nessa área? No que você acha que a sua formação em História contribuiu? E, nisso, puxamos para uma coisa que você falou lá no começo, você falou que fez muitas matérias fora do Departamento. Como você vê que essas matérias feitas fora do Departamento te ajudaram hoje como editor?

Carlos Ogawa: Eu vou começar por essa última, acho que ela é mais fácil. Olha, para trabalhar com patrimônio histórico, por exemplo, ter feito os cursos no MAE foi muito importante, porque eu trabalhei, por exemplo, com o conceito de cultura material. $\mathrm{O}$ curso de Museologia não era da grade, foi uma optativa meio que arranjada ali, de forma circunstancial pelo Departamento, ou mesmo o curso de Arqueologia da Marlene, era uma coisa muito ocasional aqui dentro. Esses cursos foram muito importantes. O estudo de Línguas aqui contribuiu um pouco para desenvolver habilidades de edição, mas não digo que é determinante, acho que foi um acaso feliz na minha história.

Eu fiz o curso da Lilia [Schwarcz] de Antropologia e História, o que contribuiu também, porque volta e meia a gente tem que lidar com questões de Antropologia um livro de História não é só de História, assim como uma pesquisa em História não se restringe aos limites da disciplina. Então, a gente sempre busca, até pela natureza da disciplina, o diálogo interdisciplinar; acho que também é por isso que a USP é tão marcante na formação das pessoas, porque ela te permite transitar pelas áreas. Numa faculdade particular você não tem isso de "ah, vou fazer um curso de História e Arqueologia da Grécia Clássica Helenística" [risos]. Não é qualquer universidade que 


\section{entrevista}

Carlos Ogawa

tem um museu de arqueologia para você estudar, mesmo para você, sei lá, estudar sambaqui, na USP você consegue. Essa amplitude da USP é muito importante.

Agora, sobre como a formação específica em História ajudou... Acho que para aguentar o ritmo de trabalho [risos], pelas leituras de mais de 100 páginas. São leituras diferentes, é claro. A experiência acadêmica, que você tem de pesquisa, ajuda porque você desenvolve algumas capacidades críticas. Para alguns trabalhos, é necessário que se passe muito tempo analisando conceitos, argumentos, estruturando o texto do autor; então, na hora em que ele não consegue dar uma forma bem acabada para um pensamento, a experiência acadêmica ajuda. Identificar conceitos, a forma como foram empregados, sem falar do repertório... Ter repertório ajuda a identificar problemas no texto, identificar pontos de vista do autor. Nesse ponto, a experiência acadêmica ajuda, mas, por outro lado, em muitas coisas que são mais técnicas da profissão, às vezes um profissional de Letras se sai muito melhor, porque ele tem outras práticas e outros conhecimentos.

Revista Epígrafe: Quais são as competências que você considera essenciais para o trabalho no mercado editorial? Independentemente de você ser historiador ou não... Qual a prática do bom editor?

Carlos Ogawa: Ah, o bom editor... É um trabalho artesanal, ainda é um trabalho artesanal, por mais que a gente tenha essa série de pressões, o essencial ainda é o editor e o texto. Então, precisa ter sensibilidade para o texto, isso é primordial; e isso não quer dizer que você tenha que ser uma pessoa formada em Letras, ou que isso não possa ser desenvolvido e aprendido, mas... A sensibilidade para o texto também é um esforço de alteridade, porque você tem sempre que pensar no texto não para si, mas para o outro, porque você não é o consumidor do texto que você está editando. 


\section{entrevista}

O aprendizado de um ofício ou um caminho pelos livros didáticos

Dependendo do tipo de livro, você realmente tem que pensar muito nisso. Se você está editando uma coleção de anos iniciais do ensino fundamental, é necessário lembrar que o seu leitor não está alfabetizado. As atividades são de "circule", "assinale"... E sempre com a mediação do professor.

Eu acho que uma segunda qualidade é você ter repertório de mundo, experiências de mundo. Não é "eu fui para a Tailândia". Não, não é isso [risos]. Está um pouco ligado a essa sensibilidade do texto, porque se você não consegue imaginar que o Brasil é um país tão multicultural e com tantas regiões diferentes, com valores diferentes... Aliás, é uma coisa que os professores reclamam muito, que os livros são todos feitos no eixo Rio-São Paulo, e que eles têm caras, e jargões, e linguagens característicos dessa região. Ter essa sensibilidade para diferentes experiências de vida e diferentes formas de você utilizar o livro em sala; diferentes perfis de professor; de sempre pensar que você não está fazendo um livro para ele ser perfeito, você está fazendo um livro para ele ser adequado.

Bom, organização... Não tem jeito, parece papo empresarial, mas quando você está com uma coleção e um volume tem 12 capítulos e cada capítulo tem 10 fotos... E você trabalha com quatro volumes, quatro volumes com 12 capítulos com 10 fotos... E é isso, a gente está falando só de foto, pode ter mapa, pode ter texto de terceiros, sei lá, ilustrações... Então, precisa ter esse controle de todos esses materiais que estão circulando, porque cada um pode estar em uma etapa diferente: briefing [de ilustração], escolha de foto, aprovação de texto... Às vezes, quando estou editando os originais do livro sete, o livro seis voltou em prova... Daí eu ainda tenho o oito e o nove para fazer [risos]. O editor precisa ser organizado, não pode deixar pendências de foto senão o livro não fecha; se o editor não atenta para a aprovação dos textos de terceiros, é possível que o proprietário dos direitos autorais tenha negado a utilização de uma parte importante de uma atividade ou de uma seção... Mas não é fim do 


\section{entrevista|}

Carlos Ogawa

mundo, não, só precisa ter controle e envolvimento com a produção, e isso às vezes acaba virando até uma coisa meio passional [risos]. Às vezes as pessoas se envolvem demais, você passa, sei lá, 12, 13 horas fazendo o negócio, você quer que saia direito [risos].

Repertório cultural também é importante, porque é isso, às vezes você está lendo alguma coisa e o autor fez uma referência, às vezes você precisa saber se a referência é apropriada ou não, em determinados contextos. Para fazer um livro é necessário ler livros. Isso é muito importante, ter repertório cultural - e isso é até um gargalo socioeconômico para a entrada na profissão. É um problema, porque capital cultural é capital. Então, às vezes uma pessoa entra mais fácil na profissão e tem mais sucesso porque ela tem capital cultural, tem um repertório pessoal mais amplo. Porém, é desejável que a pessoa tenha um bom repertório cultural até mesmo para dialogar com os autores.

Revista Epígrafe: Acho que a gente está caminhando para o fim, e temos uma última questão... Você já deu um pitaco sobre isso, mas queríamos desenvolver um pouco melhor... Que é a questão de como o conteúdo acadêmico, o conteúdo produzido na Universidade, vai parar no livro didático. Você colocou a editora, o livro didático como uma mediação entre a produção do conhecimento acadêmico e a produção do conhecimento no ensino básico. Mas como é passar esse conteúdo? Você está em contato com a academia? E acho que até mais do que isso... Os livros têm que estar atualizados no que há de mais moderno na produção acadêmica, ou não necessariamente?

Carlos Ogawa: Não é tão formal assim, são mais relações de força; um livro didático nunca é uma intencionalidade pura, ele é produto de várias relações de força e de 


\section{entrevista}

O aprendizado de um ofício ou um caminho pelos livros didáticos várias mediações. Por um lado, os professores são aqueles que de fato compram os livros... Os pais compram, mas não escolhem. Então, se o professor não aceita a coleção, ela morre, pura e simplesmente; foi o que aconteceu, por exemplo, com os livros da década de 2000 de história temática que foram publicados pela [Editora] Scipione. Os professores adotaram nos primeiros anos, mas depois a coleção deixou de vender. No último PNLD em que foi inscrita, a coleção vendeu cerca de 60 mil exemplares, o que não paga nem os custos de produção. Em muitos casos, a resposta para a pergunta "por que tal coleção tem esse perfil?" [é] porque, dentro da prática daquela editora, em relação aos professores que ela atende, as regiões, as escolas, eles pedem aquele tipo de atividade, aquele tipo de conteúdo, eles pedem um autor com aquele perfil.

A mesma coisa acontece com a academia, porque muitos professores [universitários] são autores de livros de História, muitos professores são leitores críticos, então... Se você bater nas portas [do Departamento de História da USP], você vai encontrar vários que já escreveram ou que já fizeram trabalhos; mas por outro lado, nos últimos anos, o saber acadêmico não é transposto de forma automática para o saber escolar... Esse momento já passou. A Base sinaliza isso, foi feita dentro da academia por professores universitários, mas atende demandas que são das escolas, dos governos, das empresas. Há uma série de dinâmicas aí que impactam o jeito que a transposição didática ocorre entre a academia e a editora. Um professor universitário hoje vai ter que escrever um livro de acordo com a BNCC, então há um saber que é, de certa forma acadêmico e escolar, mas que é operacionalizado pelas editoras. Não é uma transposição direta do saber acadêmico.

Revista Epígrafe: O que você acha disso? 


\section{entrevista}

Carlos Ogawa

Carlos Ogawa: O saber acadêmico é também muito fragmentado, né? A gente não trabalha mais em grandes consensos. Isso atrapalha muito na hora de você fazer a transposição didática; a gente não está mais falando daqueles debates concentrados da década de 2000. Agora, são todas micro pesquisas de temas muito fragmentados, debates muito horizontalizados, e a gente precisaria de muita gente para ler e transformar isso em consensos acadêmicos, então não é mais nessa chave que a coisa funciona. A narrativa do livro didático não é a mesma da produção acadêmica. Ainda é complicado mostrar que a natureza da produção científica é ser parcial e fragmentada. A tradição escolar tenta sempre encadear os temas em grandes narrativas. Os trabalhos acadêmicos recentes têm influência, são utilizados, mas não são a base das grandes narrativas. Aí é importante retomar as relações de força, nos condicionantes do processo. Por exemplo, hoje os livros do PNLD não têm o mesmo rendimento que já tiveram antes, de dinheiro, então o investimento provavelmente vai ser mais baixo e isso vai impactar, por exemplo, a quantidade de leituras críticas que são feitas.

Revista Epígrafe: A Revista Epígrafe é uma revista de graduação, a gente faz essas entrevistas para as pessoas conhecerem os possíveis ofícios, e a pergunta é: que dicas você daria para um estudante que quer entrar nessa área de trabalho? Por onde começar? O que fazer e como entrar nesse mundo do mercado editorial dos livros didáticos?

Carlos Ogawa: As empresas abrem programas de estágio que são até legais. Não são muitas pessoas que são contratadas, e isso é ruim... Em dois anos de estágio é possível formar um editor em começo de carreira. Aliás, sobre como o saber acadêmico passa os livros didáticos, às vezes entra uma pessoa que acabou de se 


\section{entrevista}

O aprendizado de um ofício ou um caminho pelos livros didáticos

formar e ela traz uma renovação ali. Como a disciplina é fragmentada, nem sempre conseguimos acompanhar tudo, e há sempre troca de experiências entre os colegas mais antigos e os mais novos.

Recomendo fazer os cursos introdutórios da Universidade do Livro, ainda mais que eles são on-line. Ainda há indicações, e muitas pessoas que começam a fazer freelas também acabam contratadas. E tem muita gente que olha e fala: “Não, obrigado", porque o ritmo é pesado. Voltando à pergunta, não sei se há muitos caminhos institucionalizados.

Revista Epígrafe: Caminhos únicos, né? São possibilidades, também. 